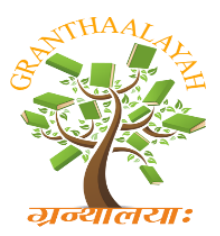

INTERNATIONAL JOURNAL OF RESEARCH GRANTHAALAYAH A knowledge Repository

\title{
SOCIETY AWARENESS AS A STRATEGY FOR CONSERVATION OF NATURAL RESOURCES
}

\author{
Babita Sengwar \\ Research Scholar, DAVV, Life Science Dept., Indore (M.P.)
}

\begin{abstract}
Conservation is the proper management of natural resources to prevent its exploitation, destruction or degradation. India is blessed with natural resources but these resources from our research study on the usage of natural resources are depleting every day. As we know nature provides all the basic needs which are necessary to us but we are over exploiting or over using these resources.

Conservation of natural resources has acquired great attention at present. It is high time that man must realize of the grave consequences of his action which are damaging the environment beyond repair. If we continue exploit the nature, there will be no more natural resources available in the future. So, there is an urgent need to conserve the nature for future. Society participation in the conservation of natural resources is vital importance so we must get them involved in this national task.

A society, a state, a country, the whole world is a collection of individuals in a final analysis. Therefore, if individual does his or her duty to perfection, the whole world can become less pollution free and we can conserve our natural resources. It is the duty of us to spread awareness among the society in this regard.
\end{abstract}

Keywords:

Conservation, natural resources, awareness, participation.

\section{INTRODUCTION}

Conservation is a practice embracing preservation, maintenance, sustainable utilization, restoration and enhancement of the natural environment. The main aim of conservation is to preservation of quality of environment and ensure continuous yield of natural resources by establishing a balanced cycle of harvest and renewal.

Depletion of natural resources, lack of water harvesting and proper waste management practices are the chief environmental problems facing the mankind at present. All these can be rectified to a great extent by creating environmental awareness among the general public. Students as an enlightened group of energetic youngsters can play a major role in bringing about this awareness in society.

\section{CONSERVING NATURE FOR FUTURE GENERATION IS THE DUTY OF THE PRESENT GENERATION}

This is our duty to prevent our earth. If we do not take care, our future generation will not get a chance to even see many of the creations of nature. We inherited a beautiful nature with a great 
variety of plants and animals from our nature and sustained by our ancestors. We are reaping all benefits from it. Now we cannot destroy the same and deny our descendants whatever we inherited.

\section{ECOTOURISM COMBINES CONSERVATION WITH DEVELOPMENT}

The revenue generated by ecotourism can be reinvested in the conservation of nature. It also provides employment opportunities to traditionally remote and marginalized communities. It increases environment awareness and creates a desire in the public mind for developing more and more tourist spot. It builds public support for conservation and encourages the participation of private sector in conservation efforts. However care must be taken that areas opened for ecotourism do not get degraded by the activities of the tourists themselves.

\section{IMPROVING SKILLS FOR CONSERVATION IN PROFESSIONS}

Professional working at different levels needs different kinds of educational skills such as planning skills, training skills, community education skills, documentation and reporting skills, evaluation skills and general managerial skills to preserve natural resources. Apart from these as a member of civil society, every person needs certain skills which are essential to protect nature. Usually these skills are taught in the academic institutions while these are acquired through training of trainer's course or passed by seniors, friends and elderly in society. But all the programs and planning must be executed and implementation liability should be imposed on each individual. However Professional working with communities must be sensitive to utilize the knowledge, approaches and the tools that are made available to them, in order to produce successful results through effective mobilization and participation of all educational proponents along with common people, with whom they work for sustainable conservation.

\section{ROLE OF WOMEN IN CONSERVATION}

Women are considered as a "Major Group" whose involvement is necessary to achieve sustainable conservation. At present there is growing emphasis on gender main streaming integrally incorporating both men's and women's concerns and participation in the planning implementations and monitoring of all development and environmental management programs.

Strategy is essential to achieve the equal participation of women in order to bring about sustainable conservation. Women have considerable knowledge and experience in managing and conserving natural resources. It is revealed that women have varied involvement in the environment conservation and development. Most of these women are actively involved in tree planting, reforestation, coastal clean-up, waste segregation and solid waste management. They also create awareness programs to enable the communities become aware about the importance of environment. The women have also developed their own informal approaches to problem solving. Rural women groups represent the first level of the institutional framework needed to ensure bottom-up development processes. The traditional knowledge of women is vital inputs to activities involved in the sustainable use of natural resources.

The women believe that the only way to protect themselves and their families is to protect the environment around them. The women also recognized the need to conserve the natural resources for the next generations and believed that they could contribute to environment conservation and development in their own personal capacities. The information campaign, training programs and seminars that are provided to the women also served as mechanism to create awareness about the relevance of a healthy environment. Moreover, these women used their creative and productive energies to work for the environment to express their deep concern for their children and future 
generations. Based on their initial experiences, women could really make a difference in terms of enlightening the minds of the community members about the importance of environment, and in harnessing the active participation of the community members in conservation and development.

\section{CONCLUSION}

The main aim of this paper is to ensure our main philosophy about the relationship between earth's resources and its environment with society participation. Hence environmental education has been identified as an essential component for sustainable conservation worldwide. The role of education can also positively influence the management of the world's increasingly stressed natural resources through the incorporation of successful techniques of environmental education. Thus it has become an added responsibility of each citizen on the globe not only to disturb nature any further but also compensate for past mistakes. This is a real sustainable conservation and real planning for future.

\section{RECOMMENDATIONS}

1. Environmental education should be mandatory part of curriculum in all streams at school and college level. It provides techniques to students with the knowledge, skills, and experiences essential to become successful community leaders, as well as making intelligent decisions pertaining to the management of their natural resources.

2. Afforestation, reforestation and forest conservation must be done on a large scale in India.

3. Environment education can generate awareness, commitment and ability to translate both in concrete actions. A sustainable environment is not possible without education that will reshape the collective consciousness and conscience and to influence everyday life. The primary goal of this is to raise environmental awareness and consciousness and actions of the majority of the population so they will be more vigilant and committed in keeping watch over the environment conservation and development.

4. Establish such effective strategies and mechanisms to increase the proportion of society particularly as decision makers, planners, technical advisers and beneficiaries in the design, development and implementation of policies and programs for natural resources management and conservation.

5. Promote the consciousness and awareness in the pupils, teachers, parents and the community people towards a balanced ecology for sustainable conservation.

6. Provide opportunities for women to participate in decision- making regarding sustainable resources management and the development of policies and programs for sustainable development.

7. Environmental protection and conservation should be the responsibility of all the citizens, regardless of gender, age, occupation, and socio-economic status.

8. Achieving sustainable environment and development will only be possible through collaborative works of society.

\section{REFERENCES}

1. Rogers J.W. John and P. Geoffrey Feiss "People and the Earth" Basic issues in the sustainability of resources and environment. Cambridge University press 1998.

2. Hampannavar U.S., Gouri Suresh “Environmental studies” I.K. International publishing house Pvt. Ltd. New Delhi 2011

3. Purohit S.S., Q.J. Shammi, A.K. Agrawal “A Text Book of Environmental science” Student Edition, 2004. 
[Social Issues and Environmental Problems, Vol.3 (Iss.9:SE): Sep, 2015] 2394-3629(P)

4. www.developmenteducationreview.com

5. www.unesco.org/education/en.
ISSN- 2350-0530(O) ISSN-

Impact Factor: 2.035 (I2OR) 